\title{
Causative effects of motivation to transfer learning among relational dyads: the test of a model
}

\author{
Brian Matthews, Jamie Daigle and Joy Cooper \\ College of Business, Engineering, and Technology, \\ Texas A\&M University Texarkana, Texarkana, Texas, USA
}

\begin{abstract}
Purpose - The purpose of this study is to validate multiplicative cycle that exists between the job readiness and satisfaction model explored by Matthews et al. (2018), the satisfaction and performance paradigmatic nuances analyzed by Judge et al. (2001) and Gu and Chi (2009), in addition to the expectancy model theorized by Vroom (1964). The motivation to transfer learning serves as a conveyable variable transmitted within a learning continuum that sustains cyclical outputs.

Design/methodology/approach - An archetype to explore the connection between the three hypothesized theories is created through a neural network program. Exploring this connection develops deeper understandings of the derivatives of employee motivation as it pertains to its effect on readiness, satisfaction, performance and achievement dyads. A detailed analysis of the literature leads to the hypothesis that the motivation to transfer learning creates a multiplicative effect among hypothesized relationships.

Findings - The neural network program scaffolds the proposed general belief that positive effects of transfer motives cause a cyclical effect that continues to perpetuate among hypothesized dyads. Conversely, if this motivation decreases or ceases among one or more dyads, the cyclical effect will retract and, eventually stop.

Originality/value - Based on the neurologic outcome, one central theme emerged: managers must offer opportunities to acquire knowledge through assistive mechanisms (i.e. training) by providing external stability through controlled channels that activates the motivation to transfer learning into new opportunities. The transference of this knowledge produces reconstructive growth opportunities through continuous learning thus increasing performance.
\end{abstract}

Keywords Achievement, Readiness, Satisfaction, Performance, Motivation to transfer learning

Paper type Research paper

\section{Introduction}

Researchers have extensively studied instrumental modes of learning transference through intrinsic and extrinsic correlates (Deci and Ryan, 1985; Lepper et al., 2005), organizational learning culture (Egan et al., 2004), learner feedback (Islam, 2019). Noe (1986) defined the motivation to transfer learning as "the learner's intended efforts to utilize skills and knowledge learned in training setting to a real-world work situation" (p. 743). Arguably, the impetus to transfer knowledge projects from the expectation that learners who convert training at work to explicit usefulness in pragmatic situations are more likely to be motivated. The successful application of newly acquired knowledge and skills elicits an attitudinal response associated with intrinsic precursors linked to self-determination theory (Baard et al., 2004) and expectancy theory (Vroom, 1964). To map a culminating destination, Elliott and Murayama (2008) pronounced instrumental and terminal values aligned with dimensionality

(C) Brian Matthews, Jamie Daigle and Joy Cooper. Published in European Journal of Management and Business Economics. Published by Emerald Publishing Limited. This article is published under the Creative Commons Attribution (CC BY 4.0) licence. Anyone may reproduce, distribute, translate and create derivative works of this article (for both commercial and non-commercial purposes), subject to full attribution to the original publication and authors. The full terms of this licence may be seen at http:// creativecommons.org/licences/by/4.0/legalcode

Causative effects of motivation

Received 20 July 2019 Revised 20 December 2019 17 February 2020

Accepted 16 March 2020 (1) 
EJMBE 29,3 based on a mastery-performance construct. Distinctively, mastery focuses on actual learning, and performance focuses on the execution of what is learned. This lends itself to Noe and Schmitt's (1986) definition of motivation as an impulsion to utilize knowledge and skills mastered during a training program on a job.

Separate research has investigated and has proposed needs theories that accent a drive to exceed intrapersonal benchmarks and meet performance outcomes (Elliott and Murayama, 2008; Kumar and Jauhari, 2016; Maslow, 1954; McClelland, 1961; Stahl, 1986). The pursuit of achievement assigns a valence or attractiveness to obtain an outcome more efficiently and robust than historically performed. While this pursuit is marred by a possible avoidance of perceived effortless or laborious tasks, the need for achievement can be linked to fear of failure. Conceptually, the need to achieve presents an inherent factor that drives expectancy and instrumentality used to influence effort and performance calculation and perceived outcomes, thus increasing job satisfaction (Vroom, 1964). At the substratum of need-based theory, the measurement of intrinsic and extrinsic sources has postured opposing effects focused on a singular dimension (Harter, 1981) until Herzberg et al. (1959) compartmentalized job satisfaction and job dissatisfaction into motivational and informational components. An amalgam of both polar effects concurrently identifies behavioral outcomes that measure emotional, physical and cognitive engagement.

While the literature contains exhaustive studies on correlative relationships between readiness and satisfaction (Hersey and Blanchard, 1982; Matthews et al., 2018), satisfaction and performance (Gu and Chi, 2009; Judge et al., 2001; Park et al., 2017) and performance and achievement (Vroom, 1964), no study can be found that captures the analysis of each dyad separately then interrelatedly links all coupled taxonomies to examine the nuanced effects of the motivation to transfer learning. It is also important to note that the repository of transfer research finds actionality within myriad academic disciplines (i.e. management, HRD, training); that is to say that trained employees can be categorized as learners (Baldwin and Ford, 1988; Clark et al., 1993; Lim and Johnson, 2002; van Merrienboer, 1997). This article aims to show the consequential recourses that exist among interlinked dyads when the motivation to transfer learning becomes an intervening force that drives convergent change throughout a controlled learning channel.

\section{Literature review}

\section{The nature of the readiness-satisfaction dyad}

Susanto (2008) defined employee readiness as a belief, intention and attitude regarding the extent to which change is needed. Armenakis et al. (1993) described readiness in terms of an employee's beliefs, attitudes and intentions. Fundamentally, readiness activities equip learners with knowledge and experience to manage and facilitate day-to-day work activities. While no singular constituent can be solely attributed to job satisfaction, employee readiness stipulated a unidirectional prominence that creates an affective or emotional response toward all facets of a job. Both Cunningham et al. (2002) and Tetenbaum (1998) posited that the readiness factor was a determining factor for successful organizational change.

Learners who had an active approach in resolving organizational problems scored highest in job readiness dimensions (Cunningham et al., 2002). Bussing et al. (1999) identified a positive correlation between job satisfaction and organizational learning theory. In the context of educational practices, contributory methods toward learning outcomes contain valid and reliable appraisals that mediate investment, increase motivation and maximize substance (Brill, 2016; Suen, 2014). Both Brill and Suen primarily focus on the procedural facilitation of learner feedback and significance of the feedback received. Job positions that place greater demands and offer a larger range of decision-making opportunities tend to show more readiness for organizational change (Shah et al., 2017). Messmer (2000) found that an 
intentional investment in work training and career development not only increases readiness but also contributes to employee retention.

Job satisfaction is not a static phenomenon and is influenced by job or work factors (Lam, 1995). The study by Walker and Campbell (2013) found that job readiness predicted job satisfaction and work engagement. Employee engagement serves as a learning process in which employee control personal behaviors and goals (Osborne and Hammoud, 2017). Additionally, this study revealed dimensions of job readiness and job satisfaction to act as mediators between job acumen and intention to stay. Job satisfaction is not a static phenomenon and is influenced by job or work factors (Lam, 1995). Other studies support readiness as a predictor in job satisfaction. A study by Walker and Campbell (2013) found job readiness predicted job satisfaction and work engagement. The study by Walker and Campbell found dimensions of job readiness and job satisfaction to act as mediators between organizational acumen and intention to stay. Hersey and Blanchard (1982) believed the consequential effect of employee readiness reflects a prescriptive model that granularly produces moderate levels of maturity through active participation in decision-making. Latif (2012) found that employee retention was majorly affected by employee-focused learning development. As learning and self-efficacy increases, they become more connected, satisfied and enthused about all facets of their job (employee readiness $\rightarrow$ job satisfaction).

The ideal relational construct that entails an autonomous and self-regulating culture within the readiness-satisfaction paradigm promotes development through delegation. According to Leana (1987), delegation promotes and encourages individual achievement by assigning individual responsibilities and authority to dependent employees. This construct is suitable for employees that view independence as an opportunity to utilize developmental mechanisms to make independent decisions. Accordingly, independence induces an acuity of sense-making systems that render cultural regulation inadequate and intentionally places learners in prescriptive learning climates that arouses cognitive growth and problem-solving dexterity.

Noe and Schmitt, 1986 posited that learners develop an affinity toward knowledge acquired through formal and informal learning climates which can alter attitudes, interests, values and perceptions toward work groups and task structure. Readiness outcomes influence behavioral changes that shift motivation to apply knowledge gained through learning to job-specific context (Egan et al., 2004). Consequently, employee expends more time and effort, assumes greater responsibility, orients and identifies with the organization. Adversely, when learners resort to withdrawing from learning activities, hiding identities, ideas and feelings, and disengaging from institutional interests, performance decreases (Deci and Ryan, 1985).

\section{The nature of the satisfaction-performance dyad}

The relationship between job performance and job satisfaction is meaningful. In an organizational context, job satisfaction is expressed through emotional responses versus something that is observed (Luthans and Thomas, 1989). According to Fatima and Azam (2016), employees view job satisfaction as the extent that job-related intrinsic and extrinsic values, such as the position, payment, opportunities, peers, are met or exceeded. Scullen et al (2000) contented that job performance plays the most significant role in personnel decisions impacting pay, promotion and retention.

The relationship between job satisfaction and job performance has been heavily researched. The Hawthorne studies conducted in the 1930s provide a catalyst to link satisfaction to performance. Following the Hawthorne studies, Brayfield and Crockett (1955) reviewed satisfaction and performance studies and found an inconsequential relationship between satisfaction and performance. A meta-analysis conducted by Iaffaldano and
Causative effects of motivation 
EJMBE 29,3

300

Muchinsky (1985) reviewed 74 previously published studies found the relationship between satisfaction and performance to be relatively low. Alessandri et al. (2017) used a latent difference score model to analyze worker satisfaction and found satisfied workers had higher performance levels over more extended periods of time versus unsatisfied workers.

Other researchers have reported significant relationships between job satisfaction and performance (Telman and Unsal, 2004). Lawler and Porter (1967) found that high performance led to higher income, increased promotions and more employee reconciliation. Al-Aameri (2000) found that satisfied learners are imaginative, devoted and emotionally attached to their employers. This study attempts to provide needed evidence to link and supplement the relationship between job performance and job satisfaction.

\section{Nature of the performance-achievement dyad}

Previous research supports employee satisfaction is positively correlated with employeeperceived organizational justice that includes the performance appraisal process (Levy and Williams, 1998). Adams (1963) interpreted employee obligation to remain with an organization is higher when there is a perceived positive relationship between one's performance effort and the performance rating. An employee's vantage point of an organization is based on individual reflections of self-beliefs. Learners use different strategies and activities to achieve performance and organizational goals. Morrow (1983) suggested that specific leadership strategies can promote an employee's self-achievement. Chi et al. (2008) postulated effective leaders motivate learners and support them to achieve and attain professional goals. Chi et al. found that employee satisfaction and organizational commitment increased when a leader's assessment of employee performance aligns with employee selfperformance and achievement.

Garg and Rastogi (2006) conjectured that more learning opportunities provide learners with the knowledge needed to perform to confront global challenges. Demonstrative opportunities correlated with achievement standards become normative in content but prescriptive in context. Implicitly, the contextual modality becomes the normative benchmark based on perceived competence, which is antecedent to achievement goals (Elliot and Murayama, 2008). Several authors (Judge et al., 2001) have reconceptualized job performance and job satisfaction typologies and derived that performance leads to satisfying value outcomes. Vroom (1964) theorized a probable perception that an exerted amount of effort produces an achievable level of performance based on conscious expectancy calculations. Locke and Latham (2000) deduced that high objectives and high expectations of success intensify efforts toward achievement based on the goals and needs of the individual (Robbins et al., 2017). Knowles (1969) suggested that the need for achievement results from an amalgamation of affective response and elevated performance levels. Therefore, if job satisfaction is based on how one feels about all aspects of a job (Ellickson and Logsdon, 2002), intrinsic and extrinsic sources have a significant causal effect on overall job satisfaction and motivation.

Learners have the tendency to adopt feelings of boredom and futility if performance goals have been exhausted and learning potentialities are depleted, due to reducing or eliminating all deficiencies with no relevant control mechanisms, thus becoming less dependent of growth externalities. In other words, learning becomes decontextualized, such that the relevance and utilization of knowledge decreases in value without available learning activities and preparation for future learning (Belenky and Nokes, 2012). A declining intrinsic presence might suggest increasing the challenge, interest and relevance of the goal. Similarly, an increase in intrinsic motivation may equate to reducing the external reward systems and contingencies connected to the performance standards (Lepper et al., 2005). Combining both learning and performance dimensions to the achievement modality increases the need for achievement. Self-conceptions become less nebulous, and incremental theories of ability are 
validated thought achievement gains. Environmental constructs become conducive to normative motivations aligned with perceiving competencies as mastery standards involve. However, Lepper et al. (2005) suggested that performance goals, while extrinsic, have been linked to decreased cognitive engagement and avoidance of challenge.
Causative effects of motivation

\section{Motivation to transfer learning among to readiness, satisfaction, performance and achievement dyads}

Porter et al. (2003) describe motivation as the force that energizes, directs and sustains behavior. Motivation consists of energy, direction and persistence (Fard et al., 2010). According to Manzoor (2012), motivation symbolizes a procedure initiated through psychological and physiological needs dispensed toward a specific objective. Kroth (2007) postulated that motivation might increase with work customization. Notably, motivation is the product of an exponential reverberation of expectancy, instrumentality and the attractiveness of the specified goal (Vroom, 1964). Implicit and explicit reinforcement form a modeled behavior if presented with positive incentives or rewards. Harter (1981) suggested that the collaboration between intrinsic interests and extrinsic rewards acts as a tool to motivate learning. Maehr and Nicholls (1980) inferred that an intrapersonal requisite generates a subjective standard for learning used to evaluate competency as a part of goal achievement to measure mastery.

Skinner (1953) theorized that behaviors that result in positive outcomes are recurrent, and behaviors that result in adverse outcomes are not. If the valence of the reward lacks an affective investment, the individual can conceivably become demotivated, although a certain level of effort was calculated and exerted, the performance was achievable, and the reward was certain. Contrariwise, the presence of a practical component can be counterintuitive and operationalize ways to avoid mastery attempts for fear of failure. Mastery-based standards assess competency levels based on the positive possibility to succeed or a staunch avoidance of failure (Elliot and Harackiewicz, 1996). Motivation through intrinsic and extrinsic sources reinforces behaviors that are learned better, given more attention and performed more often (Robbins et al., 2017).

Lunenburg (2011) explained that a multiplicative effect that construes (1) an exertion of deliberate effort would produce a perceived level of performance, (2) a perceived level of performance is instrumentally manipulated in procuring the desired outcome and (3) an allocated value is advertently attached to the outcome or reward. Meaning, if $\mathrm{A} \neq \mathrm{B}, \mathrm{B} \neq \mathrm{A}$, or if $\mathrm{C}=0$, then no motivation exists. If an individual believes that expending a certain level of effort will produce a heightened level of performance, however, if the improbability of being rewarded is substantiated, then the individual becomes demotivated. Alternatively, if an individual assumes the probability of being rewarded for a certain level of performance but appraises the effort needed to perform a task successfully as impossible, the individual will not be motivated and avoid the task.

Conversely, learners can cognitively evaluate situational contexts and determine deficient psychology and emotional deficiencies. The theoretical scaffold is construed by models that emphasize the behavior $\rightarrow$ attitudes (attitudes follow behaviors) paradigm (Dickson, 1973). Consequently, the negative feedback loop stops and growth potential halts. Heylighen (1992, 2014) asserted that the virtue of openness to experience creates an eagerness to undergo new experiences, learn new ideas and skills and trying new things. Accordingly, existing schemas and ego-cultures are contradicted, resulting in the challenge of schematic acuities. This venture into the unknown motivates self-actualizers to intuitively and rationally understand contradictory perceptions while purposely detracted from denying, repressing or deforming novel observations. Subtly, there exists a predisposed notion enact competitive undertones existent between the mastery- and performance-approach. The need to master certain task 
EJMBE 29,3

\section{2}

Figure 1.

Cyclical effect connecting readiness, satisfaction, performance and achievement. Note that motivation to transfer learning is an internal variable present of each dyad levels suggestively affects performance levels, which augments the need to learn more (Harackiewicz et al., 1998). Tendencies to exponentially strengthen self-efficacy increases while maintaining an intrapersonal control that creates an awareness of oneself. The goal becomes actualized when conceptualizing the learning activity as a cognitively represented aim separated by the intentionality for pursuing the goal (Elliot and Thrash, 2001).

\section{Theoretical framework and model}

This study aims to examine a reconceptualized framework that disaggregates theoretical relationships to measure the multiplier effect, or motivational sequence, based on hypothesized dyad conjectured by theory or empirical research. This study examines the multidimensional coupling of relational correlates and the associative effects of learning transfer among each dyad. The proposed theoretical framework assumes the disposition of systems theory; meaning that behavior of each relational dyad directly affects the overall behavior of the entire transfer system. Rather than triggering an independent effect on the entire system, each dyad has associative effects that are interdependent and work interconnectedly to move toward equilibrium within the entire system (Skyttner, 1996).

Specifically, the cyclical model (see Figure 1), using elements of the double transfer model (cf. Figure 1, Schwartz and Martin, 2004) implies that acquired knowledge generates a motivation to transfer learning in real-world situations, which initiates competence awareness (readiness), or mastery-approach (Elliott and Murayama, 2008). Knowledge is believed to be transferred out if its use is suitable to solve new problems outside the boundaries of the original learning construct (Belenky and Nokes, 2012). As readiness increases attributable to repetitive usages of knowledge, behavioral retorts are mediated by intrinsic factors (i.e. autonomy and environmental control) that trigger a favorable effect (satisfaction). The readiness-satisfaction dyad denotes the origin of learning characterized by hands-on inventions or instructional activities (Schwartz and Martin, 2004). Equally, knowledge acquired transfer out through a feedforward mechanism that helps mitigate the fear of failure and increase pre-emptive measures to reduce uncertainty (Goldsmith, 2003).

As satisfaction increases, customized arrangements of activities are intentionally compiled to accomplish a specific goal or set of goals (performance) as knowledge transfers through the learning continuum or channel. Within the transfer climate (e.g. work environment), concurrent controls symbolize supervisory and peer support, opportunities to perform and accountability (Burke and Hutchins, 2007). Several researchers addressed leadership theories that denoted the latitudinal empowerment (i.e. influence in decisionmaking, open communications, confidence) and independence given by subordinate-oriented boss (Hersey and Blanchard, 1982; Tannenbaum and Schmidt, 1975; Harris et al., 2011).

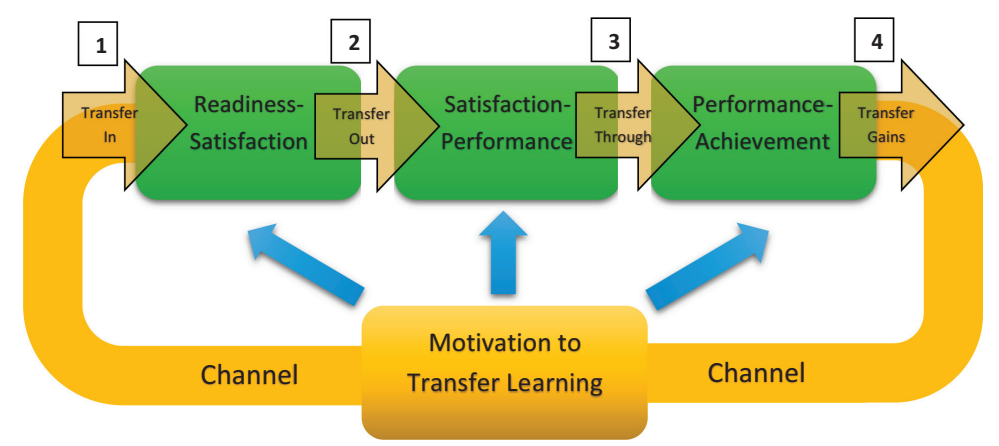


According to Vroom (1964), performance levels based on calculative efforts exerted results in the accomplishment of the goal itself (achievement). When culminated at the end of the continuum, knowledge amassed through replicative uses within the channel is now suitable to be transferred into new learning situations (Belenky and Nokes, 2012). After achievement goals are complete and evaluated, learning interventions can be designed to provide learners with timely feedback, reinforcement and remediation to help improve the mastery-approach (Lee and Kahnweiler, 2000; Salas et al., 1999). Belenky and Nokes (2012) found that learners who were able to experience procedural invention and instructional activities into worked examples prior to the prospective problem increased in motivation to transfer in learning to new learning situations.

The theory assumes a causal effect that signifies an evolution of mastery after achievement is reached. Learning transfer and mastery-approach remain the pivotal variables that drive the exponential change throughout the cyclical recurrence. Specifically, motivation and learning act as proximal filters that foster intrinsic properties that externally regulate the outward transference of learning in a situationally, physically and emotionally governed channel (Baard et al., 2004; Gegenfurtner et al., 2009). The channel acts as a conduit in which mastery becomes a derivative product of replicative learning and is granularly attained over time (Baldwin and Ford, 1988). The range between readiness and achievement where acquired knowledge become applicative and replicative within controlled environments are proximal predictors that generate achievement outputs such as intrinsic motivation and performance attainment (Elliott and Church, 1997).

The model postulates the following theoretical linear and cyclical sequence: (1) knowledge and skills gained by the employee through hands-on inventions or instructional activities are transferred in to new learning situations, (2) transferred out to solve problems external of its origin point by performing task- or situation-specific activities, (3) utilized and transferred through the learning continuum to achieve goals and (4) assessed to determine transfer gains (increase in learning) that will be used to transfer in to new and upcoming situations. This cycle of transference stimulates the employee inwardly (emotionally and cognitively) as the flow of learning (knowledge and skills) (Noe and Schmitt, 1986) transmits among relational dyads while outputs of each dyad (i.e. application of knowledge, performing tasks, completion of goals) are produced outwardly (situationally and empirically).

As achievement success increases, complicated tasks are more likely selected as personal challenges are dominated (Bigge and Hunt, 1980), and constructive appraisals are provided. Conversely, if achievement success declines, more manageable tasks are more likely to be selected to reduce the fear of failure. At this juncture, competency-based on intrapersonal standards of absolute mastery is demoted self-conceptions of ability (Elliott and Murayama, 2008). Intrapersonal incompetence and task-based avoidance become antecedents to performance-avoidance, which fails to scaffold intrinsic motivation as a relevant contributor in part (Elliott and Murayama, 2008). To surmise, if the motivation to transfer learning increases among all dyads, the cycle perpetuates. Alternatively, if transfer learning decreases, the cyclical progression either ceases to initiate, protract or discontinue.

\section{Hypothesis and methodology}

Based on the literature surrounding job performance and satisfaction paradigms and expectancy theory, this article tests the following hypothesis:

(1) Hypothesis 1: An increase in motivation to transfer learning among one or more relational dyads generates a continual cyclical effect among readiness, satisfaction, performance and achievement.
Causative effects of motivation 
EJMBE 29,3

304
(2) Hypothesis 2: A decrease in motivation to transfer learning decreases among one or more relational dyads generates a cyclical effect that protracts or rests.

(3) Alternative Hypothesis 1: Motivation to transfer learning has no effect on any relational dyad and no cyclical effect occurs.

This study aims to test if a direct link exists between Matthews et al. (2018) readinesssatisfaction dyad, Park et al. (2017) satisfaction-performance dyad, and Vroom (1964) performance-achievement dyad. This study is conducted through a critical realist and pragmatic paradigm which justifies a mixed-methods approach that incorporates qualitative and quantitative data within a neural network. This research finds it necessary to capture the richness of business societal interactions through a mixed-methods approach as one methodology does not capture the complexities of the interconnected systems. This study fills a literary gap by utilizing neural networks to create empirical and rational knowledge that incorporates the quantitative side, which is often neglected in motivational research studies.

This research utilizes triangulation in a quantitative and qualitative sequential mixedmethods approach by combining conceptual frameworks of the dyads through a neural network methodological approach. Similarly, Modic et al. (2019) conduct a study that discusses using neural networks to choose an appropriate method and then integrating both qualitative and quantitative data through machine learning. When choosing an approach, this research turned to the related literature to choose an appropriate methodological framework, illustrated in Figure 2, to apply to this research study.

This study layers the satisfaction-performance dyad (Park et al., 2017) on top of the performance-achievement dyad and readiness-satisfaction dyad to understand how motivation accelerates, slows and possibly halts throughout each node of the network. Through this approach, we created an algorithm that allows us to model the dyad cycle with a machine learning neural network to understand the flow of motivation energy through the progression of the variables. The Artificial Neural Network, or ANN, utilizes a binary system to codify the level of motivation energy that exits between each biological cell within the neural network. Then, after the algorithm is codified into a binary numerical system, it will

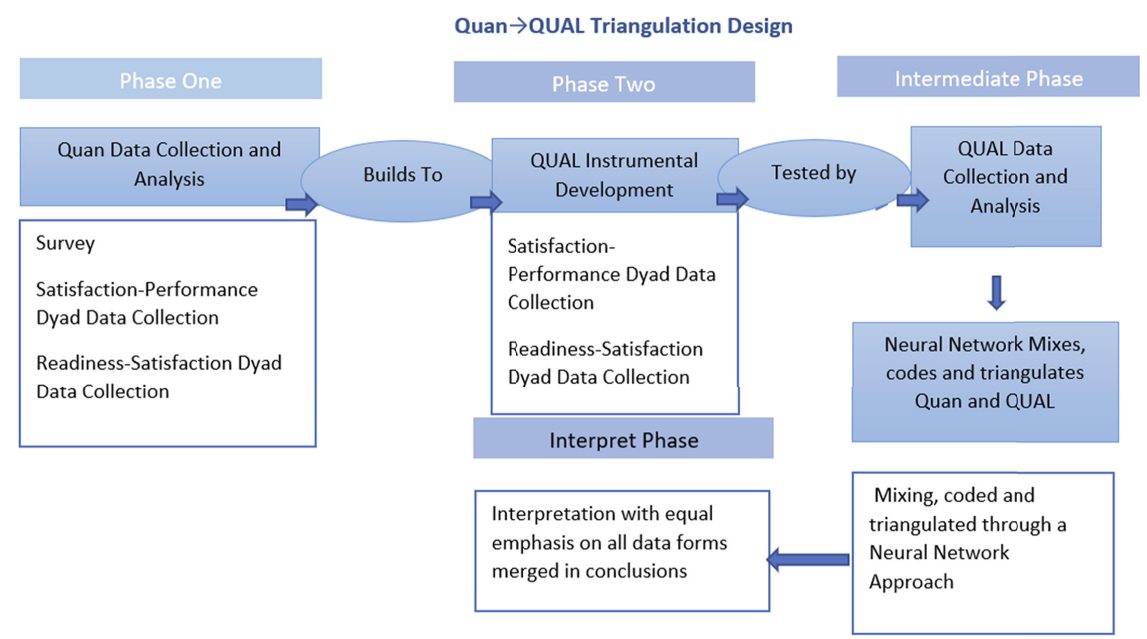

Source(s): Tashakkori and Teddlie (1998) and Herzberg et al. (1959)
Figure 2.

Quan $\rightarrow$ QUAL triangulation design 
flow through a threshold logic unit to derive the energy to fire through the biological process. If the TLU is positive, then it can fire through the next biological cell and flow through the dyads. Using a threshold logic unit to derive outcomes, this simulation method measures how energy impacts the dyads throughout the biological cell cycle with a multiplier effect.

To program the neural network model for the readiness satisfaction dyad, each variable is assigned the appropriate Likert scale as assigned by the research survey outcomes and weighed by the neural network. The survey tool establishes eight choices for leader-member relations, four choices for maturity level and willingness to do the work, four choices for Hersey and Blanchard (1982) situational leadership theory, seven hygiene factors based on a 1-10 satisfaction on a Likert scale, and the level of actualization based upon Maslow's Hierarchy of Needs (see Figure 3).

Figure 4 shows the leader-member relations portion of the algorithm is determined by four maturity levels, as researched by Hersey and Blanchard (1982) and are assigned their appropriate letter designations.

Hersey and Blanchard's (1982) situational leadership theory is based on a dyad between leadership style and the maturity level of those being led. Within this dyad, leadership styles

\begin{tabular}{|l|l|}
\hline $\begin{array}{l}\text { Readiness Satisfaction Dyad Algorithm: RSD=lmrl }>\mathbf{I V} \rightarrow \mathbf{m I} \geq \mathbf{3} \rightarrow \mathbf{h b} \geq \mathbf{3} \rightarrow \mathbf{h} \mathbf{I} \geq \mathbf{5} \rightarrow \mathbf{M} \geq \mathbf{3} \text { - } \\
\mathbf{R S D}=\mathbf{l m r} \mathbf{1}<\mathbf{V} \rightarrow \mathbf{m l} \leq \mathbf{2} \rightarrow \mathbf{h b} \leq \mathbf{2} \rightarrow \mathbf{h f} \leq \mathbf{5} \rightarrow \mathbf{M} \leq \mathbf{2} \text { RS }\end{array}$ \\
\hline Variable Code & Measurement \\
\hline $\mathrm{W}$ & Weight \\
\hline $\mathrm{lmr}$ & leader-member maturation \\
\hline $\mathrm{Ml}$ & Maturity level \\
\hline $\mathrm{hb}$ & $\begin{array}{l}\text { Hersey-Blanchard situational leadership } \\
\text { theory }\end{array}$ \\
\hline $\mathrm{IV}$ & $\begin{array}{l}\text { Category 4 on the leader-member correlation } \\
\text { matrix }\end{array}$ \\
\hline $\mathrm{hF}$ & $\begin{array}{l}\text { Hygiene factors } \\
\text { Category 5 on the leader-member correlation } \\
\text { matrix }\end{array}$ \\
\hline $\mathrm{M}$ & $\begin{array}{l}\text { Maslow's hierarchy of needs actualization } \\
\text { level }\end{array}$ \\
\hline
\end{tabular}

Sources(s): Maslow (1954); Hersey and Blanchard (1982); Vroom (1964)
Causative effects of motivation

305
Figure 3.

Readiness-satisfaction dyad algorithm

\begin{tabular}{|l|l|}
\hline M-1 & $\begin{array}{l}\text { basic incompetence or unwillingness in doing } \\
\text { the task }\end{array}$ \\
\hline M-2 & inability to do the task but willing to do so \\
\hline M-3 & $\begin{array}{l}\text { competent to do the task but do not think they } \\
\text { can }\end{array}$ \\
\hline M-4 & $\begin{array}{l}\text { the group is ready, willing, and able to do the } \\
\text { task. }\end{array}$ \\
\hline
\end{tabular}

Source(s): Hersey and Blanchard (1982)

Figure 4.

Leader-member exchange dyad algorithm 
EJMBE 29,3

\section{6}

Figure 5.

Leadership style coding stem from four basic behaviors, designated with a letter-number combination. The algorithm assigns the appropriate number to the respective leadership style, which is represented in Figure 5 below.

Then, the survey measures the level of satisfaction of the following hygiene factors:

(1) Supervisors;

(2) Working conditions;

(3) Interpersonal relations;

(4) Pay and security and

(5) Company policies and administration.

Next, the neural network assigned the actualization level on Maslow's hierarchy of needs pyramid. The number assignment designation is as follows: (1) psychological, (2) safety, (3) belongingness, (4) esteem and (5) self-actualizations.

To see how motivation increased, decreased or halted performance energy, the model overlaid readiness satisfaction with the satisfaction performance to understand the flow of motivational energy. Vroom's (1964) model of performance achievement makes the indications of the TLU to measure energy outcomes. In the research of Vroom, three variables indicated motivation, which included the linkage of A performance and effort, $B$ the linkage of performance and rewards, and $\mathrm{C}$ attractiveness or valence. In other words, if $\mathrm{A} \neq \mathrm{B}$, $\mathrm{B} \neq \mathrm{A}$, or if $\mathrm{C}=0$, then no motivation exists.

Then, the ANN overlays the research of Park et al. (2017), which determines why high performers feel dissatisfied when role overload (resource outflow) exists and how external resources impact performance and role satisfaction (resource inflow). The research of Park et al. discovered that role overload decreased high performers' job satisfaction. The leadermember exchange social comparison (LMXSC) increased high performers' job satisfaction because of the exclusive resources attained. According to this study, job satisfaction was lowest when resource outflow from role overload was not traded off by the resource inflow of LMXSC (Park et al., 2017). Figure 6 represents the algorithmic utilization of the machine learning employed to communicate among dyadic nodes.

Finally, the weight for each variable, as determined by the ANN, is passed through a sigmoid function to codify it into a binary construct. This summation is then normalized through a sigmoid function:

$$
\frac{1}{1+e^{-x}}
$$

\section{Sample}

The sample selection for this study is guided by the sampling methods utilized by researchers perusing to understand readiness-satisfaction, satisfaction-performance, performanceachievement motivation and organizational learning (Fard et al., 2010; Gu and Chi, 2009; Matthews et al., 2018; Poloski-Vokic et al., 2008; Vroom, 1964). This study utilizes a

\begin{tabular}{|l|l|}
\hline S-1 & Telling \\
\hline S-2 & Selling \\
\hline S-3 & Participating \\
\hline S-4 & Delegating \\
\hline
\end{tabular}

Source(s): Hersey and Blanchard (1982) 
probability and deliberate sampling approach to obtain information about employee and employer relational dyads in a simulation within the workforce population of east Texas. Survey data of 320 supervisor-employee dyads across seven major industries in the East Texas region are collected in this study. The sample includes 160 supervisors and 160 lowerranking employees. The demographics of supervisory level respondents include a mean age of 47 years, with 15 years of industry-related experience, and reports an average tenure of four years in their current roles. The nonsupervisory component of the data sample includes respondents with a mean age of 32 years, seven years of experience in their fields, and three years of tenure in their current roles. The sample includes $55 \%$ men and $45 \%$ of women participants. Figure 7 represents additional details about the sample utilized in this research study.

\section{Data results}

This study accepts the hypotheses that motivation to transfer learning creates a multiplier effect among the readiness-satisfaction dyad when learning is present, which triangulates Matthews et al. (2018), the satisfaction-performance dyad from Park et al. (2017) and the performance-achievement dyad of Vroom (1964). The data substantiate the multiplicative effect of job readiness, satisfaction, performance and achievement, both positively and negatively, depending on the trajectory of the motivational factor, even when learning is present. Thus, the presence of motivation causes a cyclical effect that perpetuates among relational dyads. The data reveal that when motivation wanes or ceases among one or more

\begin{tabular}{|l|l|}
\hline \multicolumn{2}{|c|}{ LMXSC $\uparrow \mathbf{J S}=$ LMR + JS-D $\rightarrow$ RO } \\
\hline Variable Code & Measurement \\
\hline RO & Resource Outflow \\
\hline D & Dissatisfaction \\
\hline LMXSC & Leader-member exchange social comparison \\
\hline JA & Job Satisfaction \\
\hline
\end{tabular}

Source(s): Hersey and Blanchard (1982); Matthews et al. (2018); Park, Chae, and Kim (2017); Vroom (1964)
Causative effects of motivation
Figure 6.

Machine learning process algorithm for neural network



Figure 7.

Research sample for machine learning process 
EJMBE 29,3

\section{8}

Figure 8.

The causality between motivation and readiness, satisfaction, performance and achievement dyadic dyads, the cyclical effect begins to retract and, eventually, stop. The implication of ignoring the applied effect that motivation has on job readiness, satisfaction, achievement and performance leave researchers and managers with ineffective and nonapplicable models to judge the motivational phenomenon.

Based on the neural network model computations, the results are statistically significant, with a $p$-value of 0.00 . Further the $\mathrm{R} 2$ indicates that the readiness-satisfaction dyad, the satisfaction-performance-dyad and the performance-achievement dyad have an R2 of $88 \%$, signifying a direct correlation. The SD when commutating the survey results from the dyadic comprises readiness, satisfaction, performance and achievement without motivation resulted in 3.89, whereas the standard 2.53, which makes motivation a variable that sways consistency toward positive performance outcomes. The standard error of the mean dropped from 0.22 to 0.14 when motivation was present. The following chart presents the statistical outcomes of satisfaction, readiness, performance and achievement in this research study.

The null hypothesis is rejected and both alternative hypotheses are accepted as the $t$-statistic of 0.20 is less than the critical two tail distribution of 0.84 . Moreover, the line graph (see Figure 8) presents the exactitude at which correlation is generated.

The algorithm yielded $\mu=6.0$ in the sample that did not incorporate motivational vectors and $\mu=2.95$ with an underlying motivational driver (see Table 1 ).

Interestingly, the difference between both valuations was 3.05 , which indicates that motivation is a substantial multiplier effect across performance, achievement and readiness. Furthermore, the neural network model was successful in back-propagating motivation and how it impacts the dyads through a cyclical feedback loop.

\section{Discussion and conclusion}

A neural network approach is used in this study to triangulate if a multiplicative exacerbation exists when motivation transpires between nodes to understand the effect of transfer learning among dyads. This study shows that an elevated presence of motivation to transfer learning serves as a prerequisite to maintain an active cyclical and recursive effect between all hypothesized dyads. Inversely, when motivation to transfer learning decreases among dyads, the cyclical effect theoretically retracts and, eventually, stops. Marginal opportunities to actively use acquired skills on the job directly impedes transfer learning while opportunities to utilize trained skills constitute a prerequisite to successful knowledge transfer (Clarke, 2002; Lim and Johnson, 2002).

The continual presence of motivation to transfer learning and the correlative effect on each dyad show a progressive transfer of knowledge persists when intrinsic and extrinsic






\begin{tabular}{|c|c|c|c|c|c|}
\hline \multicolumn{2}{|c|}{$\begin{array}{l}\text { Readiness, satisfaction, performance and } \\
\text { achievement dyads with motivation }\end{array}$} & \multicolumn{2}{|c|}{$\begin{array}{l}\text { Readiness, satisfaction, performance and } \\
\text { achievement dyads with motivation }\end{array}$} & \multirow{2}{*}{$\frac{\text { Difference }}{3.05390625}$} & \multirow{2}{*}{$\begin{array}{l}\text { Causative } \\
\text { effects of } \\
\text { motivation }\end{array}$} \\
\hline Mean & 6.003125 & Mean & 2.94921875 & & \\
\hline Standard error & 0.217468467 & Standard error & 0.141879952 & 0.07558852 & \\
\hline Median & 5.5 & Median & 2.75 & 2.75 & \\
\hline Mode & 0 & Mode & 0 & 0 & \\
\hline $\mathrm{SD}$ & 3.890194197 & SD & 2.538025733 & 1.35216846 & 309 \\
\hline Sample Variance & 15.13361089 & Sample Variance & 6.441574633 & 8.69203627 & \\
\hline Kurtosis & 0.273043432 & Kurtosis & 0.034275479 & 0.23876795 & \\
\hline Skewness & 0.640601599 & Skewness & 0.767640106 & -0.12703851 & \\
\hline Range & 20.75 & Range & 11 & 9.75 & \\
\hline Minimum & -0.75 & Minimum & 0 & -0.75 & Table 1 \\
\hline Maximum & 20 & Maximum & 11 & 9 & Statistical outcomes of \\
\hline Sum & 1921 & Sum & 943.75 & 977.25 & readiness, satisfaction, \\
\hline Count & 320 & Count & 320 & 0 & performance and \\
\hline Confidence level $(95.0 \%)$ & 0.427853635 & Confidence level $(95.0 \%)$ & 0.279138645 & 0.14871499 & achievement \\
\hline
\end{tabular}

cues remain resonate in mastery-approach and achievement goals. This study further establishes a dyadic linkage between the job readiness and satisfaction model Matthews et al. (2018), the satisfaction and performance (Gu and Chi, 2009; Judge et al., 2001) and the expectancy model (Vroom, 1964). The continual presence of motivation and the correlative effect on paradigmatic variables show progressive matriculation through relational dyads that persist if intrinsic and extrinsic factors remain to resonate in goal attainment.

According to the neural network model, the findings indicate that as motivation to transfer learning increases among one or more relational dyads, a multiplier effect stimulates a continuous loop among readiness, satisfaction and performance. The implications of ignoring the applied effect that motivation has on readiness, satisfaction, achievement and performance leaves managers with ineffective and nonapplicable models to judge the motivational phenomenon. Gegenfurtner et al., (2009) emphasized the simultaneous presence of self-determination theory (Baard et al., 2004) and expectancy theory (Vroom, 1964), which decisively administers cognitive-choice and need-motive-choice approaches that theoretically predicts and empirically explain human performance. The implicit and explicit cruxes within the unidirectional channel reflect internally motivated behavior used to assess an intrapersonal assessment of competence and externally prompted reasons to transfer knowledge within a controlled environment applicably.

Based on the theoretical framework used in this study, motivation to transfer learning governs concentrated efforts and performance energy (motivation) indicative of foreshadowing outcome actualizations. Vroom (1964) and Herzberg et al. (1959) asserted that the nexus between expectancy and goal attainment congregates valuative calculations of assumptive performance outputs within environments with combined intrinsic (motivators) and extrinsic (hygiene) factors which generate an affective response creating a transfer climate suitable for mastery- and performance-approach. Increasingly focused on hygiene factors, Colquitt et al. (2000) found a strong correlation between environmental climate (channel) and transfer activities. Additionally, environmental climates need vetting before knowledge transference becomes the expectant catalyst to increase skill application (Burke and Baldwin, 1999; Richman-Hirsch, 2001). Lim and Johnson (2002) found that higher transfer activities were more prevalent when achievement goals matched departmental goals.

The motivational model created by the neural network within this study was substantiated with statistical accuracy and validated the amalgam of effects of motivation as learners reach a 
EJMBE 29,3 higher level of readiness, satisfaction, performance and achievement through homogeneity of lower-level phenomena. Based on this derivative, managers must focus on incorporating and linking local decisions derived from the transfer of knowledge (transfer in) to daily work operations (transfer out) that significantly align individual performance outcomes to systemic organizational goals can further encourage the transfer of learning (Lim and Johnson, 2002). Furthermore, job design should be centered on one's skills, abilities and preferences (Robbins et al., 2017). This customization can purportedly match one's self-efficacy, whether task- or situation-specific (Bandura, 1997). Barron and Harackiewicz (2001) found that circumstantial situations mediate adaptive patterns of learning based on extrinsic motives associated with performance goals. Managers should (1) develop task- and situation-specific training activities there are aligned with intrinsic cues and organizational goals, (2) provide learning transfer mechanisms of positive feedback loops that develop capacities, thus meeting intrapersonal standards of improving remaining potentialities and (3) create structured climates suitable for learning convey transfer gains into new situations.

\section{References}

Adams, J.S. (1963), "Towards an understanding of inequity", Journal of Abnormal and Social Psychology, Vol. 67 No. 5, pp. 422-436.

Al-Aameri, A.S. (2000), "Job satisfaction and organizational commitment for nurses", Saudi Medical Journal, Vol. 21 No. 6, pp. 531-535.

Alessandri, G., Borgogni, L. and Latham, G.P. (2017), "A dynamic model of the longitudinal relationship between job satisfaction and supervisor-rated job performance", Applied Psychology, Vol. 66 No. 2, pp. 207-232.

Armenakis, A.A., Harris, S.G. and Mossholder, K.W. (1993), "Creating readiness for organizational change", Human Relations, Vol. 46 No. 6, pp. 681-703.

Baard, P.P., Deci, E.L. and Ryan, R.M. (2004), "Intrinsic need satisfaction: a motivational basis of performance and well-being in two work settings", Journal of Applied Social Psychology, Vol. 34, pp. 2045-2068.

Baldwin, T.T. and Ford, J.K. (1988), "Transfer of training: a review and directions for future research", Personnel Psychology, Vol. 41, pp. 63-105.

Bandura, A. (1997), Self-efficacy: The Exercise of Control, Freeman, New York.

Barron, K.E. and Harackiewicz, J.M. (2001), "Achievement goals and optimal motivation: testing multiple goal models, Journal of Personality and Social Psychology, Vol. 80 No. 5, pp. 706-722.

Belenky, D.M. and Nokes, T.J. (2012), "Motivation and transfer: the role of achievement goals in preparation for future learning", The Journal of the Learning Sciences, Vol. 21 No. 3, pp. 399-432.

Bigge, M.L. and Hunt, M.P. (1980), Psychological Foundations of Education: An Introduction to Human Motivation, Development, and Learning, Harper \& Row, New York.

Brayfield, A.H. and Crockett, W.H. (1955), "Employee attitudes and employee performance", Psychological Bulletin Vol. 52 No. 5, pp. 396-424.

Brill, J.M. (2016), "Investigating peer review as a systemic activities for developing the design knowledge, skills, and dispositions of novice instructional design students", Educational Technology Research \& Development, Vol. 64 No. 4, pp. 681-705.

Burke, L.A. and Baldwin, T.T. (1999), "Workforce training transfer: a study of the effect of relapse prevention training and transfer", Human Resource Management, Vol. 38 No. 3, pp. 227-243.

Burke, L.A. and Hutchins, H.M. (2007),"Training transfer: an integrative literature review”, Human Resource Development Review, Vol. 6, pp. 263-296.

Bussing, A., Bissels, T., Fuchs, V. and Perrar, K.M. (1999), "A dynamic model of work satisfaction: qualitative approaches", Human Relations, Vol. 52, pp. 999-1028. 
Chi, H.K., Yeh, H.R. and Yu, C.H. (2008), "The effects of transformation leadership, organizational culture, job satisfaction on the organizational performance in the non-profit organizations", The Journal of Global Business Management, Vol. 4 No. 1, pp. 129-137.

Clarke, N. (2002), "Job/work environment factors influencing training transfer within a human service agency: some indicative support for Baldwin and Ford's transfer climate construct", International Journal of Training and Development, Vol. 6 No. 3, pp. 146-162.

Clark, S.C., Dobbins, G.H. and Ladd, R.T. (1993), "Exploratory field study of training motivation: influence of involvement, credibility, and transfer climate", Group \& Organization Management, Vol. 18, pp. 292-307.

Colquitt, J.A., LePine, J.A. and Noe, R.A. (2000), "Toward an integrative theory of training motivation: a meta-analytic path analysis of 20 years of research", Journal of Applied Psychology, Vol. 85 No. 5, pp. 678-707.

Cunningham, C.E., Woodward, C.A., Shannon, H.S., MacIntosh, J., Lendrum, B., Rosenbloom, D. and Brown, J. (2002), "Readiness for organizational change: a longitudinal study of workplace, psychological and behavioural correlates", Journal of Occupational and Organizational Psychology, Vol. 75 No. 4, pp. 377-392.

Deci, E.L. and Ryan, R.M. (1985), Intrinsic Motivation and Self-Determination in Human Behavior, Plenum, New York, NY.

Dickson, W.J. (1973), "Hawthorne experiments”, in The Encyclopaedia of Management, Van Norstrand Reinhold, New York.

Egan, T.M., Yang, B. and Bartlett, K.R. (2004), "The effects of organizational learning culture and job satisfaction on motivation to transfer learning and turnover intention", Human Resource Development Quarterly, Vol. 15 No. 3, pp. 279-301.

Ellickson, M.C. and Logsdon, K. (2002), "Determinants of job satisfaction of municipal government employees”, Public Personnel Management, Vol. 31 No. 3, pp. 343-358.

Elliot, A.J. and Church, M.A. (1997), "A hierarchical model of approach and avoidance achievement motivation”, Journal of Personality and Social Psychology, Vol. 72, pp. 218-232.

Elliot, A.J. and Harackiewicz, J.M. (1996), "Approach and avoidance achievement goals and intrinsic motivation: a mediational analysis", Journal of Personality and Social Psychology, Vol. 70, pp. 461-475.

Elliott, A.J. and Murayama, K. (2008), “On the measurement of achievement goals: critique, illustration, and application”, Journal of Educational Psychology, Vol. 100 No. 3, pp. 613-628.

Elliot, A.J. and Thrash, T.M. (2001), "Achievement goals and the hierarchical model of achievement motivation”, Educational Psychology Review, Vol. 12, pp. 139-156.

Fard, H.D., Ghatari, A.R. and Hasiri, A. (2010), "Employees morale in public sector: is organizational trust an important factor?", European Journal of Scientific Research, Vol. 46 No. 3, pp. 378-390.

Fatima, Z. and Azam, M.K. (2016), "Effect of salesforce control system and supervisory behaviour on job satisfaction of salespeople: a review of studies", Management Dynamics, Vol. 16 No. 2, pp. $1-11$.

Garg, P. and Rastogi, R. (2006), "New model of job design: motivating employees' performance", Journal of Management Development, Vol. 25 No. 6, pp. 572-587.

Gegenfurtner, A., Festner, D., Gallenberger, W., Lehtinen, E. and Gruber, H. (2009), "Predicting autonomous and controlled motivation to transfer training", International Journal of Training and Development, Vol. 13, pp. 124-138.

Goldsmith, M. (2003), “Try feed forward instead of feedback”, Journal for Quality and Participation, pp. 38-40.

$\mathrm{Gu}, \mathrm{Z}$. and Chi, R.S.S. (2009), "Drivers of job satisfaction as related to work performance in Macao casino hotels: an investigation based on employee survey", International Journal of Contemporary Hospitality Management, Vol. 21 No. 5, pp. 561-578.
Causative effects of motivation 
EJMBE 29,3

Harackiewicz, J.M., Barron, K.E. and Elliot, A.J. (1998), "Rethinking achievement goals: when are they adaptive for college students and why?", Educational Psychologist, Vol. 33, pp. 1-21.

Harris, K.J., Wheeler, A.R. and Kacmar, K.M. (2011), "The mediating role of organizational embeddedness in the LMX-outcomes relationship”, The Leadership Quarterly, Vol. 22 No. 2, pp. 271-281.

Harter, S. (1981), "A new self-report scale of intrinsic versus extrinsic orientation in the classroom: motivational and informational components", Developmental Psychology, Vol. 17 No. 3, pp. 300-312.

Hersey, P. and Blanchard, K.H. (1982), Management of Organizational Behavior: Leading Human Resource, Prentice Hall, Englewood Cliffs, NJ.

Herzberg, F., Mausner, B. and Snyderman, B. (1959), The Motivation to Work, Wiley, New York, NY.

Heylighen, F. (1992), "A cognitive-systemic reconstruction of Maslow's theory of self actualization”, Behavioral Science, Vol. 37, pp. 39-57.

Heylighen, F. (2014), "Challenge propagation: towards a theory of distributed intelligence and the global brain”, Spanda Journal, Vol. 10 No. 2, pp. 51-63.

Iaffaldano, M.T. and Muchinsky, P.M. (1985), "Job satisfaction and job performance: a meta-analysis", Psychological Bulletin, Vol. 97 No. 2, pp. 251-273.

Islam, T. (2019), "Motivation to transfer training in learning organizations", Journal of Management Development, Vol. 38 No. 4, pp. 273-287.

Judge, T.A., Thoresen, C.J., Bono, J.E. and Patton, G.K. (2001), "The job satisfaction-job performance relationship: a qualitative and quantitative review", Psychological Bulletin, Vol. 127 No. 3, pp. 376-407.

Knowles, G. (1969), “The achievement motive and education”, Educational Leadership, Vol. 27 No. 3, pp. 311-317.

Kroth, M. (2007), "Maslow-move aside! A heuristical motivation model for leaders in career and technical education", Journal of Industrial Teacher Education, Vol. 44 No. 2, pp. 5-36.

Kumar, M. and Jauhari, H. (2016), "Satisfaction of learning, performance, and relatedness needs at work and employees' organizational identification”, International Journal of Productivity and Performance Management, Vol. 65 No. 6, pp. 760-772.

Lam, S.S. (1995), "Quality management and job satisfaction: an empirical study", International Journal of Quality \& Reliability Management, Vol. 12 No. 4, pp. 72-78.

Latif, K.F. (2012), "An integrated model of training effectiveness and satisfaction with employee development interventions", Industrial \& Commercial Training, Vol. 44, pp. 211-222.

Lawler, E.E.III and Porter, L.W. (1967), "The effect of performance on job satisfaction", Industrial Relations: A Journal of Economy and Society, Vol. 7 No. 1, pp. 20-28.

Leana, C.R. (1987), "Power relinquishment versus power sharing: theoretical clarification and empirical comparison of delegation and participation”, Journal of Applied Psychology, Vol. 72 No. 2, pp. 228-233.

Lee, C.D. and Kahnweiler, W.M. (2000), "The effect of a mastery learning technique on the performance of a transfer of training task", Performance Improvement Quarterly, Vol. 13 No. 3, pp. 125-139.

Lepper, M.R., Corpus, J.H. and Iyengar, S.S. (2005), "Intrinsic and extrinsic motivational orientations in the classroom: age differences and academic correlates", Journal of Educational Psychology, Vol. 97, pp. 184-196.

Levy, P.E. and Williams, J.R. (1998), "The role of perceived system knowledge in predicting appraisal reactions, job satisfaction, and organizational commitment", Journal of Organizational Behavior, Vol. 19 No. 1, pp. 53-65.

Lim, D.H. and Johnson, S. (2002), "Trainee perceptions of factors that influence learning transfer", International Journal of Training and Development, Vol. 6 No. 1, pp. 36-48. 
Locke, E.A. and Latham, G.A. (2000), A Theory of Goal Setting \& Task Performance, Prentice Hall, Englewood Cliffs, NJ.

Lunenburg, F.C. (2011), "Expectancy theory of motivation", International Journal of Management, Business, and Administration, Vol. 15 No. 1, pp. 1-6.

Luthans, F. and Thomas, L.T. (1989), "The relationship between age and job satisfaction: curvilinear results from an empirical study-a research note", Personnel Review, Vol. 18 No. 1, pp. 23-26.

Maehr, M.L. and Nicholls, J.G. (1980), "Culture and achievement motivation: a second look", in Warren, E. (Ed.), Studies in Cross-Cultural Psychology, Vol. 3, Academic Press, New York, pp. 221-267.

Manzoor, Q. (2012), "Impact of employee motivation on organizational effectiveness", Business Management and Strategy, Vol. 3 No. 1, pp. 1-12.

Maslow, A. (1954), Motivation and Personality, McGraw-Hill, New York.

Matthews, B., Daigle, J. and Houston, M. (2018), "A dyadic of employee readiness and job satisfaction: does there exist a theoretical precursor to the satisfaction-performance paradigm?", International Journal of Organizational Analysis, Vol. 26 No. 5, pp. 842-857.

McClelland, D.C. (1961), The Achieving Society, Van Nostrand Reinhold, New York.

Messmer, M. (2000), “Orientations programs can be key to employee retention”, Strategic Finance, Vol. 81 No. 8, pp. 12-15.

Modic, D., Hafner, A., Damiji, N. and Zacj, L. (2019), "Innovations in intellectual property rights management", European Journal of Management and Business Economics, Vol. 12 No. 2, pp. 189-199.

Morrow, P.C. (1983), "Concept redundancy in organizational research: the case of work commitment", Academy of Management Review, Vol. 8 No. 3, pp. 486-500.

Noe, R.A. (1986), “Trainees' attributes and attitudes: neglected influences on training effectiveness", Academy of Management Review, Vol. 11 No. 4, pp. 736-749.

Noe, R.A. and Schmitt, N. (1986), "The influence of trainee attitudes on training effectiveness: the test of a model", Personnel Psychology, Vol. 39, pp. 497-523.

Osborne, S. and Hammoud, M.S. (2017), "Effective employee engagement in the workplace", International Journal of Applied Management and Technology, Vol. 16 No. 1, pp. 50-67.

Park, J., Chae, H. and Kim, H.J. (2017), "When and why high performers feel job dissatisfaction: a resource flow approach", Social Behavior and Personality, Vol. 45 No. 4, pp. 617-628.

Poloski-Vokic, N., Klindzic, M. and Dakovic, M. (2008), "Work motivation of highly educated Croatian employees-what should managers and hr experts know?", South East European Journal of Economics and Business, Vol. 3 No. 1, pp. 89-96.

Porter, L., Bigley, W.G.A. and Steers, R.M. (2003), Motivation and Work Behavior, McGraw-Hill/Irwin, Boston, MA.

Richman-Hirsch, W.L. (2001), "Post training interventions to enhance transfer: the moderating effects of work environments", Human Resource Development Quarterly, Vol. 12 No. 2, pp. 105-120.

Robbins, S.P., Coulter, M. and DeCenzo, D.A. (2017), Fundamentals of Management, Pearson, Boston, MA.

Salas, E., Cannon-Bowers, J.A., Rhodenizer, L. and Bowers, C.A. (1999), "Training in organizations: myths, misconceptions, and mistaken assumptions", in Ferris, G. (Ed), Research in Personnel and Human Resources Management, Vol. 17, JAI Press, Greenwich, CT, pp. 123-161.

Schwartz, D.L. and Martin, T. (2004), "Inventing to prepare for future learning: the hidden efficiency of encouraging original student production in statistics instruction", Cognition and Instruction, Vol. 22 No. 2, pp. 129-184.

Scullen, S.E., Mount, M.K. and Goff, M. (2000), "Understanding the latent structure of job performance ratings", Journal of Applied Psychology, Vol. 85 No. 6, pp. 956-970.

Shah, N., Irani, Z. and Sharif, A.M. (2017), "Big data in an hr context: exploring organizational change readiness, employee attitudes and behaviors”, Journal of Business Research, Vol. 70, pp. 366-378.
Causative effects of motivation

313


EJMBE 29,3

Skinner, B.F. (1953), Science and Human Behavior, The Macmillan Company, New York.

Skyttner, L. (1996), General Systems Theory: An Introduction, Macmillan Press, London.

Stahl, M.J. (1986), Managerial and Technical Motivation: Assessing Needs for Achievement, Power, Affiliation, Praeger Publications, New York.

Suen, H.K. (2014), "Peer assessment for massive open online courses (MOOCs)", The International Review of Research in Open and Distributed Learning, Vol. 15 No. 3, pp. 312-327.

Susanto, A.B. (2008), "Organizational readiness for change: a case study on change readiness in a manufacturing company in Indonesia", International Journal of Management Perspectives, Vol. 2 No. 1, pp. 51-62.

Tannenbaum, R. and Schmidt, W.H. (1975), "How to choose a leadership pattern”, Harvard Business Review, Vol. 51, pp. 162-180.

Tashakkori, A. and Teddlie, C. (1998), Mixed Methodology: Combining Qualitative and Quantitative Approaches, Sage Publications, Thousand Oaks, CA.

Telman, N. and Unsal, P. (2004), Employee Satisfaction, Epsilon Publishing, Istanbul.

Tetenbaum, T.J. (1998), "Shifting paradigms: from Newton to chaos", Organizational Dynamics, Vol. 26 No. 4, pp. 21-33.

van Merrienboer, J.J.G. (1997), Training Complex Cognitive Skills: A Four-Component Instructional Design Model for Technical Training, Educational Technology Publications, Englewood Cliffs, NJ.

Vroom, V.H. (1964), Work and Motivation, John Wiley and Sons, New York.

Walker, A. and Campbell, K. (2013), "Work readiness of graduate nurses and the impact on job satisfaction, work engagement and intention to remain", Nurse Education Today, Vol. 33 No. 12 , pp. $1490-1495$.

\section{Corresponding author}

Brian Matthews can be contacted at: brian.matthews@tamut.edu

For instructions on how to order reprints of this article, please visit our website:

www.emeraldgrouppublishing.com/licensing/reprints.htm

Or contact us for further details: permissions@emeraldinsight.com 